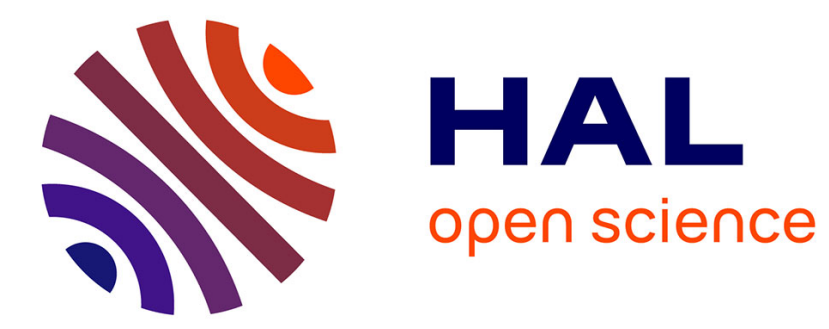

\title{
Social norms on working hours and peak times in public transport
}

Emmanuel Munch

\section{To cite this version:}

Emmanuel Munch. Social norms on working hours and peak times in public transport. Time and Society, 2020, 29 (3), pp.836-865. 10.1177/0961463X20905478 . hal-02537128

\section{HAL Id: hal-02537128 \\ https://hal.science/hal-02537128}

Submitted on 7 Oct 2021

HAL is a multi-disciplinary open access archive for the deposit and dissemination of scientific research documents, whether they are published or not. The documents may come from teaching and research institutions in France or abroad, or from public or private research centers.
L'archive ouverte pluridisciplinaire HAL, est destinée au dépôt et à la diffusion de documents scientifiques de niveau recherche, publiés ou non, émanant des établissements d'enseignement et de recherche français ou étrangers, des laboratoires publics ou privés. 


\title{
Social norms on working hours and peak times in public transport
}

Time \& Society 2020, Vol. 29(3) 836-865

(C) The Author(s) 2020

Article reuse guidelines: sagepub.com/journals-permissions DOI: 10.1 | 77/096|463X20905478

journals.sagepub.com/home/tas

@SAGE

\section{Emmanuel Munch $\mathbb{D}$}

Department of Sociology, University of Bologna, Italy / Research Unit City Mobility Transport, University of Eastern Paris, France

\begin{abstract}
What employee with the right to choose their own working hours has not felt the silent weight of critical reproach from their colleagues or their boss when they arrive later than most at work? Although this is a form of social control that seems widespread in the world of French flexitime, it is a subject that has so far received very little scholarly attention in research on day-to-day temporalities. Yet in the era of flexible working hours, the persistence of daily peak commuting periods could be partly explained by the presence of implicit timekeeping norms in the workplace. In this article, therefore, we try to demonstrate the existence of 'social norms on working hours' that continue to put pressure on flexitime workers to arrive at the office at the same time as their colleagues. Drawing on a field survey conducted in big companies in the Paris region, we show that there exist two types of social norms on working hours that directly contribute to morning peak-time transport congestion: 'the norm of the disciplined worker' and the 'norm of the dedicated executive'.
\end{abstract}

\section{Keywords}

Peak-hour, working hours, executives, flexitime, synchronisation, temporal norms, social control, Paris region

\footnotetext{
Corresponding author:

Emmanuel Munch, Department of Sociology, University of Bologna, Italy / Research Unit City

Mobility Transport, University of Eastern Paris, France

Emails: emmanuel.munch@unibo.it; emmanuel.munch@enpc.fr
} 


\section{Introduction}

In the era of the 'post-industrial city' (Godard, 2007) and of flexible working hours, this article seeks to explain the persistence of morning rush-hour phenomena from the original perspective of social norms on working hours.

As described by François Ascher (1998), in the typical Western industrial city up to the end of the 1960s, working hours were primarily dictated by macrosocial forces that he associated with 'temporal orders'. The industrial temporal order was embodied in factory time clocks and sirens, and was simply the reflection of ironclad corporate and temporal discipline. Dictated by production needs and the scientific organisation of work (Lefebvre, 2002 [1961]; Thompson, 1967), it resulted in standard working days typically lasting from 8:30 a.m. to 5:30 p.m. (Baudoin, 1975), but also in phenomena of peak-time transport congestion.

Today, with the rise of the service economy and the 'dematerialisation' of production activities in the big urban centres (Castells, 1996), an everincreasing proportion of the working population is able to access working hours that are no longer subject to the explicit ordinance of the employer. The term for this situation is 'flexible working hours' or 'flexitime'. Although when they emerged in the late 1960s, these adjustable working hours were a managerial policy intended to allow employees to travel to work outside rush-hour periods (Pierce and Newstrom, 1980; Thoemmes, 2013), up to now their effectiveness in reducing congestion remains to be proven.

In fact, empirical studies in Belgium, England, France and in the Netherlands have shown that the removal of collective regulatory constraints on working hours does not lead to workers staggering their morning start times (Breedveld, 1998; Burkinshaw, 2018; Glorieux et al., 2008; Lesnard, 2006). In fact, it seems that where several companies are clustered within a single area, it has the reverse effect. Indeed, recent research has shown that in the Paris region, flexitime is associated with morning start times that are more concentrated within the morning peak period (Munch, 2017).

This paradox raises questions about the schematic way we historically think about the causes of synchronised working hours, and conversely about what would bring about their desynchronisation. The cause of travel synchronisation during the industrial era, on the one hand, and the factors driving their desynchronisation during the post-industrial period, on the other, are supposed to provide a before and after image of the impact of the organisation of work on the rush-hour phenomenon: in 
the former case, the standardised working hours set by employers were the cause of the excessive synchronisation of commuting times; in the latter, the end of employer-imposed working times is expected to contribute to the desynchronisation of morning travel.

However, this explanatory picture runs counter to recent research findings. Collective regulation of working hours cannot be the main cause of rush-hour phenomena, since when the rules are relaxed or removed, peak-time travel - contrary to expectations - becomes more concentrated. In light of this, in conditions where a growing proportion of employees in Paris have a degree of contractual freedom in choosing the time they start work, the objective of this article is to identify the causes of the rush-hour phenomenon by looking at the microsocial scale of office life.

Specifically, we explore the question of social norms on working hours and their potential effect on work schedule choices that apparently lead to peaktime arrivals. Our aim is to verify whether, through social control mechanisms employed by colleagues and management, Parisian employees with flexible working hours nevertheless find themselves obliged to arrive at work before 9:30 a.m. in order to avoid the disapproval of their work collective.

The exploration of social norms relating to working hours and transport opens up a dialogue with more general research on social temporalities. We are thinking, in particular, of the works by Hartmut Rosa (2013) which describe more globally the paradoxical link between freedom in the choice of working hours and the marked synchronisation of work schedules. For him, the fact that modern subjects are so free and individualistic and at the same time so regulated and coordinated in temporal terms, is because 'they are governed, dominated and repressed by a temporal regime that is largely invisible, depoliticised, undiscussed, under-theorised and unarticulated' (Rosa, 2013: 8).

In circumstances where more and more 'modern subjects' enjoy the freedom to choose their working hours, we therefore seek to spotlight and discuss the 'temporal regime' that contributes to the current synchronisation of working hours, and therefore to the perpetuation of rush-hour phenomena.

In our view, the fact that commuting peaks continue to exist is evidence that the synchronisation of daily activities has not been disrupted but operates differently and perhaps less visibly. In other words, individuals no longer necessarily receive orders or explicitly segmented temporal norms imposed from above. Instead, they themselves become the appointed overseers and monitors of social norms on working hours that come from below and are formalised within the workplace. According to this argument, social 
norms on working hours differ from the temporal norms dictated by the factory siren because they are markedly less obtrusive. They are usually crystallised through the mirror of other people's eyes (Mead, 2015 [1934]) and the fear of being labelled: what will my colleagues and managers think if I get into work at 10 o'clock? Or else: so-and-so arrives early - they must be professional and committed. In this interactionist approach, our interest is thus specifically the time at which 'an employee is seen to "arrive" at work'. Although it is becoming increasingly commonplace for people to start work earlier with email and laptops, the issue here is not the real start of work, but the actual time when a worker's presence is apparent to the work collective.

Despite what this specific approach to the social norms of working hours contributes to research, it can also limit the scope of the findings that we will describe. These limitations need to be borne in mind even before one begins to consider the findings. Our special access to the working world of large enterprises in Île-de-France exposes us to rationales that are associated almost entirely with the workplace. However, as many authors (Ariès and Duby, 1999; Belton-Chevallier, 2009) have noted, it should not be forgotten that everyday timeframes and working hours are structured by reference to every kind of day-to-day activity (sleep, meals, family life, consumption, leisure). It would be rash to imagine that workers with flexible hours continue to arrive at work at peak times solely because they are subject to temporal norms that can be observed in their workplace. All the explanatory factors that contribute to the structure and synchronisation of work arrival times (mealtimes, school drop-off times, shop opening times, leisure timetables...) were investigated together in this research, but they are discussed in another article (Munch, 2019). In this paper, therefore, we deliberately ignore the temporal norms that form outside work, in order to analyse as precisely as possible only the temporal norms established within the work collective.

In this article, through a review of the literature on the sociology of time, we will first describe the theoretical framework we used to define 'social norms on working hours' and will explain the heuristic scope of this concept. We will then describe how we detect the presence and outlines of these social norms through a survey in five workplaces in Plaine Saint-Denis, a service sector hub in northern Paris. Finally, through the words of employees who are mostly mid-level executives with flexible working hours, and then through an experiment with their HR managers, ${ }^{1}$ we will show that there are two types of social norms that channel morning start times: the 'norm of the disciplined worker' that penalises arrivals at the office in the post-peak period and the 'norm of the dedicated executive' that rewards arrivals in the pre-peak period. 


\section{For a heuristics of social norms on working hours}

This section is divided into three parts. It offers a dialogue between the notions of peak times, working hours and social norms. Drawing on a summary of the social science research on these questions, it will lead us step-by-step to a definition of the concept of 'social norms on working hours'.

\section{Disciplinary barriers between transport times and working times}

The problem of rush-hour transport congestion is usually a research topic in the field of traffic engineering (Vickrey, 1969). In consequence, the approach to the question of the simultaneity of working hours tends to be superficial (Thorauge et al., 2016), since the focus is on the aggregate and cumulative phenomenon of peak-time travel and not on its possible causes. The work schedule as a social practice that underpins the problem of the rush hour has received very little attention. It remains an exogenous factor that is essentially seen as inert to this level of analysis.

By contrast, the sociology of time (Hubert, 1929 [1905]; Pritchard, 2011 [1940]; Szalaï, 1972; Zerubavel, 1981) has historically considered objects which are necessarily factors that affect the temporalities of daily travel: social times, temporal norms, working time duration... However, when the ins and outs of working hours are discussed, they are never associated with the question of the rush hour.

This lack of linkage between the different disciplines dedicated to studying the time dimension of phenomena hampers our understanding of the problems relevant to scientific research (Grossin, 1996). That is why we propose here to draw on sociological approaches to construct the conceptual framework of 'social norms on working hours' and thereby make a contribution to ideas about the problem of peak times.

\section{Sociology of time and of work: the norms of working time duration}

According to recent work by Paul Bouffartigue (2012), at the start of the 21 st century, two main types of norms on working time duration seem to be present in France for employees in executive and/or management positions: the 'Fordian norm' and the 'flexible norm'. Under the Fordian norm, working hours are predictable and synchronised. It is associated with the enduring figure of the employee in the 'industrial city' and produces standard working days lasting approximately seven hours. The flexible norm is characterised by working hours that correspond more clearly to the timeframes of the 'post-industrial city' (Ascher, 1998; Godard, 2007), naturally associated with individuals in managerial or executive roles. It produces more variable and longer working days, lasting approximately 10 hours. 
Except that here, the temporal norms are conceptualised only in terms of the length of the working day, not the work schedule. That having been said, the standardisation of how long activities last is intimately linked with the standardisation of the time at which the activity is supposed to take place (Zerubavel, 1981). For example, the fact that a university lecture occurs between 2 p.m. and 3 p.m. is linked with the fact that it lasts one hour. The fact that a movie screening takes place between 2 p.m. and 4 p.m. is linked with the fact that the combined duration of advertisements and a film is around two hours. The time schedule of an activity is necessarily associated with the duration of the activity. In consequence, the two norms on working time must lead to two norms on working hours that will be the subject of this article. So we would note, on the one hand, that according to the French National Institute of Statistics and Economic Studies' (INSEE) most recent Time Use Survey (Sautory and Zilloniz, 2015), the seven-hour working days associated with the Fordian norm lead in France to work schedules that typically run from 8:30 a.m. to 5:30 p.m. ${ }^{2}$ On the other hand, the long, 10hour working days associated with the flexible norm lead to work schedules in the region of 7:30 a.m. to 8 p.m. ${ }^{3}$

The second mismatch between these studies and our research objectives lies in the scale and approach adopted in analysing these norms. True, the norms that determine the duration and standard schedule of the working day developed out of a constant back-and-forth between the movements of the labour market (Bouffartigue, 2012) and the legal rules setting the permitted duration and schedules (Devetter, 2001): the first Aubry Act on the 35-hour week, the reduction in working hours and the development of part-time work (Estrade et al., 2001), the second Aubry Act on the annualisation of working hours (Bunel, 2004), more flexible Sunday working (Boulin and Lesnard, 2016). Nevertheless, from our point of view, these norms cannot only be shaped through top-down and macrosocial channels, created by 'legal rules'. That is why we will focus on the consistency of social norms (rather than legal norms) that can be observed at the microsocial scale of the individual company. In so doing, we will adopt an interactionist approach (Blumer, 1969; Mead, 2015 [1934]) to study the shared representations and the 'social rules' that channel work schedule practices on the ground.

\section{Definition of the concept of social norms on working hours}

To define a social norm, we need to consider the symbols and values associated with it. The values that frame the actions of individuals produce in succession patterns of thinking, patterns of conduct and ways of behaving (Pillon, 2003), and therefore ways (times) of arriving at work. It is therefore important to emphasise that if we wish to study and observe the behaviours 
of individuals in terms of the collective values they share, it is better to concentrate on the actual form they take, i.e. the ways of behaving that they have in common. We will call these shared behaviours social norms. They can be defined as practical rules of behaviour that reflect collective values in practice (Pronovost, 1996).

We will therefore concentrate on the practical impact that these norms have on social life within service sector companies in order to try to detect their presence. The main specificity of our theoretical apparatus resides in our use of two distinct norms on working hours. We will link these two social norms with two groups of workers and with two kinds of values, which we will separate analytically but are nevertheless often interwoven in the professional life of management level employees. So when we associate certain discourses and certain interviewees with adhesion to a first type of value and social norm, and certain other discourses and other interviewees with adhesion to a second type of value and social norm, it should be remembered that these categories are primarily useful for the production of knowledge and should not systematically be seen as enfolding individuals and their practices within the boxes that we construct.

The first group encompasses the entire ensemble of employees. Here, the majority norm is perhaps out of step with contemporary management values, but nevertheless accounts for the majority of practices: this is the 'timekeeping norm of the disciplined worker' which compels individuals to arrive at work at the same time as everyone else, and in particular not after the morning travel peak. What is at stake here is primarily a time of arrival at work that would be considered normal in the sense of being socially accepted by and socially acceptable to the work collective. In keeping with the dual nature of social norms, these working hours are on the one hand positively legitimised by the values associated with salaried employment, such as effort and discipline (Foucault, 1975) and more generally with the scientific organisation of working time (Weber, 1904). On the other hand, in our observations, we primarily focus on deviant and late arrival times that may be perceived and penalised by others as socially unacceptable (Epstein, 1988).

The second group is the subgroup of management level employees or cadres in French (Boltanski and Goldhammer, 1987; Gadéa, 2003). The term cadre is itself distinctively French, and has no exact equivalent in the English language (Dupré and Lallement, 2007). The French word cadre refers to an occupational classification that confers, on the one hand, certain legally codified rights and privileges usually associated with managerial or administrative authority within an organisation such as a private-sector firm (Schulz, 2015). On the other hand, at the time of their appearance (in 
national statistics) in the 1930s, cadres were already distinguished from other professional categories by their responsibilities and autonomy. It means that they were described as "trusted employees who internalise the imperatives of the company, represent the directors and do not count their hours' (Monneuse, 2014: 22). Surveys of French cadres have confirmed the existence of a substantial gulf between the average workweeks of typical cadres and the average workweeks of French workers, even though the Aubry II work-hours framework (2000) limiting the average weekly workload to 35 hours is supposed to apply to both types of employees (Cousin, 2004). In consequence, from these tacit agreements regarding the definition of executive status in France, there emerges the possibility of a second social norm on working hours: the 'timekeeping norm of the dedicated executive'. Unlike the majority norm that applies to employees in general, this norm does not result in penalties for individuals who fail to match up to it, but instead distinguishes and rewards executives who demonstrate dedication to their company. Here, the rules of the norm game compel executives with flexible hours to spend maximum time at work and potentially to arrive before everybody else - before the peak hour - in order to make a good impression.

\section{Field survey in Plaine Saint-Denis}

The purpose of this second part is to present the survey terrain and the methodological choices employed to verify our research hypothesis.

\section{The Plaine Saint-Denis service hub and the companies surveyed}

The observational terrain is in a sense a close-up of a relevant sample, i.e. of a zone that in principle permits a more precise approach to the problem. Let us see how the profile of the companies surveyed meets this expectation (Table 1):

First, the survey sample fits well with the requirements of our research question, because the 9000 people in our five partner companies are mainly middle management level employees with flexible working hours (a range of tolerated arrival times or self-selected working hours). ${ }^{4}$ In this way, the sample provides a relatively homogeneous profile of employees who particularly interest us here. This is the figure of the 'office worker', whose workplace is in a tower block, often a large service company located in a big city. However, we could not be entirely satisfied with a sample that only generated uniform profiles. That is why different sectors were included in the survey: Banking, Insurance, Telecommunications and 'Public Transport'. The main activities that characterise the different service companies are 


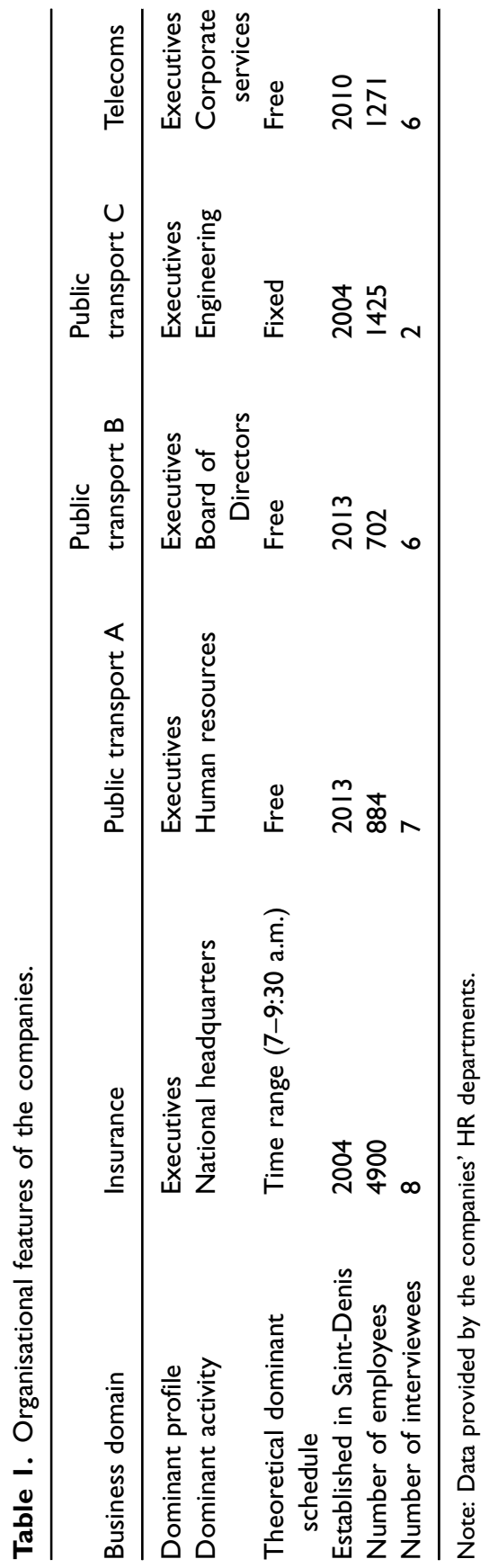


also fairly varied. They range from management and supervisory activities, to engineering, human resources and 'corporate services'. Finally, we conducted our surveys in both public and private enterprises. The purpose of this organisational diversity is to ensure that the working time practices that we study are not too heavily governed by a particular type of activity.

Second, in terms of location, the companies surveyed are located in the Plaine Saint-Denis business district, which is home to some 40,000 jobs in northern Paris. This sector is in close proximity to two SNCF stations, La Plaine - Stade de France (RER B) to the East, and Stade de France - SaintDenis (RER D) to the West. The area is particularly interesting in terms of peak-time congestion problems, in that it has experienced a job explosion: between 2000 and 2016, more than a million square metres of offices were built here, ${ }^{5}$ making Plaine Saint-Denis one of the main hubs in Paris region for service sector activities and management level jobs.

Finally, the survey location matches the imperatives of our research subject because employees in the Plaine Saint-Denis district tend globally to describe a pattern of workplace arrival times that corresponds to the average pattern of workplace arrival in the Paris region. According to the figures in the last Global Transport Survey (2010), ${ }^{6} 8-9: 29$ a.m. is the period when the most people in the Paris region arrive at work on public transport: $43.6 \%$ of weekday arrivals are concentrated in that period. ${ }^{7}$ In our study area and according to the exit data acquired on the RER D for every working Monday in 2015 (Figure 1), ${ }^{8}$ the peak arrival time in the employment zone is also between 8:30 and 9:29 a.m.: $45.1 \%$ of workplace arrivals in Plaine Saint-Denis occur during this period. By arriving within this timeslot, our employees are therefore very likely to contribute to peak-time congestion on public transport in the Paris region.

\section{Comprehensive interviews with the employees}

In terms of methodology, our survey instruments need to be able to reveal the existence of social norms, either by the presence of a social forfeit for those who fail to obey the norm of the disciplined worker or by the presence of a social benefit for those who adhere to the norm of the dedicated executive. In short, we need to be able to detect how work collectives punish arrivals that occur after the morning peak, i.e. after 9:30 a.m., and how they reward arrivals before the morning peak, i.e. prior to 8:30 a.m. However, in the day-to-day lives of employees, the manifestations of these norms are not so easy to observe as our explanations suggest.

That is why we chose to conduct semi-structured interviews with 29 employees to allow them to explain and reconstruct the rationales 


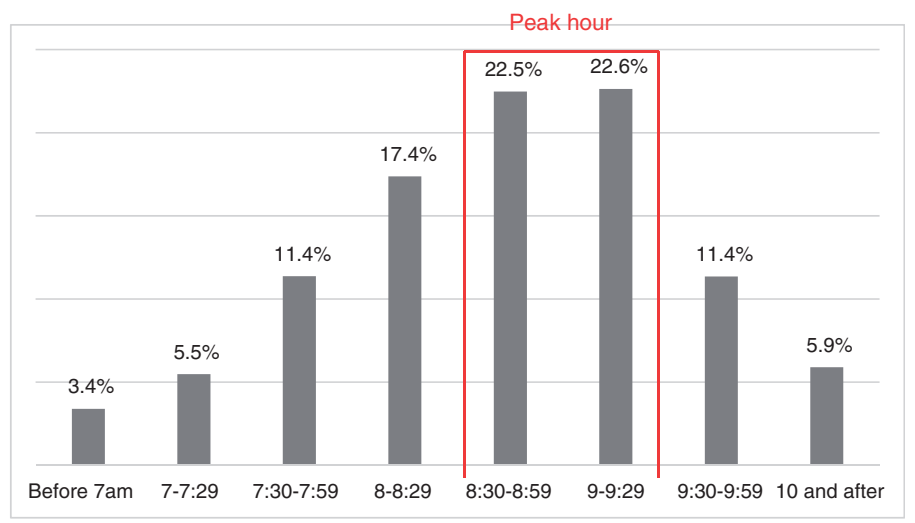

Figure I. Distribution of exit times from Stade-de-France Saint-Denis Station, by 30-minute slot.

Legend: At Stade-de-France Saint-Denis Station, $22.6 \%$ of exits on working Mondays in 2015 took place between 9 and 9:29 a.m.

Source: Station exit monitoring data for all working Mondays in 2015. Pôle TVV-SNCF Transilien.

governing their working patterns. To this end, we decided to adopt the 'comprehensive interview' method (Kaufmann, 1996) in order to obtain detailed information that often becomes lost in the mechanical and routine repetitiveness of everyday life (Elias, 1992 [1984]; Leroi-Gourhan, 1965).

The employees who took part in the semi-structured interviews (29 interviews) were recruited following a questionnaire-based survey (3202 responses). After completing the questionnaire, our subjects volunteered to participate in an interview. Rather than seeking to construct a sample of interviewees that would be representative of the survey population, this recruitment method (Kaufmann, 1996) aims to obtain a self-selecting sample of the people most concerned by the problem of managing their day-to-day work and travel schedules. ${ }^{9}$

\section{The Challenge Décale: Revealing norms conveyed by HR managers}

For the part of the survey with HR managers, the approach is quite different. In our research, we were able to observe very concretely how the HR managers in our five companies evaluate morning arrival times and penalise late arrivals. To explain: in the course of 2015, our five companies took part in the development of a competitive game, the Challenge Décalé (off-peak challenge), designed to reward employees who arrive at work outside the peak hour. By taking part in the discussions that led HR managers to 
determine the arrival timeslots that they wished to reward (the periods before and after the peak hour), we were able to grasp directly how they (de)value some workplace arrival times more than others. These observations revealing the timekeeping norms encouraged by HR managers will be the subject of the last part of our discussion.

\section{The norm of the disciplined worker}

We will begin by using the employee interviews to study how the timekeeping norm of the disciplined worker enjoins the people in our survey to arrive at the office before 9:30 a.m. In our discussion of this norm, we will show that the social environment of employees who are apparently free in fact bristles with 'boundaries' that prevent them moving freely through the corridor of working hours. The social control and forfeits imposed by department heads or colleagues become realities that give substance to the argument regarding the persistence of the timekeeping norm of the disciplined worker.

\section{The manager as authority and exemplar}

As with any mechanism of social learning, it is above all the 'old-timers' the people with the most prestige or power - who, through their function as models or authorities, are the vehicles of social norms (Pronovost, 1996): the parents in the home, the teacher at school or the manager at the office, all these people play an important role in disseminating the collective values of timekeeping discipline. As a result, although collective timetable rules may have disappeared on paper, working hour norms can nevertheless be explicitly dictated by the manager:

You have managers who are super strict on the question of working hours, despite the range of arrival times. It is as if giving freedom to employees undermined their power. (Caroline, fortyish, divorced with a child, living in the Outer Ring, senior executive, arrival around 9 a.m.)

Nonetheless, the adjustment of employees to the manager's timetable is typically more spontaneous. Managers, on the one hand, are aware of their need to set an example. And employees, on the other hand, are aware that the manager is the role model whose behaviour sets the example to follow.

This managerial role or habitus (Bourdieu, 2002) is, however, ill-suited to today's new working conditions. By contrast with the industrial era, work in the kinds of offices we study here no longer requires all 'workers' 
to be present at the same time. Yet through the uninterrupted force of work socialisation by contact with other managers, these ways of thinking about working hours have persisted. This phenomenon of the persistence of behavioural rules, or a timelag in adapting customs to the objective conditions of existence, can be defined by the notion of hysteresis, ${ }^{10}$ a concept that is central in interpreting timekeeping practices that otherwise might seem absurd today. As we learn from Mathias, currently a team leader, he continues, despite himself, to reproduce the patterns of thought that were previously passed on to him by his own bosses:

But we all tend to reproduce the patterns we have experienced ourselves. Although my tendency is to be highly flexible, in other words I don't have to come into work, I can work from home, yet despite all that, if someone in my team arrives at 10 o'clock every morning, my first reaction will be: hey, wow, what's that about, coming in at 10. And after that, I start thinking straight and tell myself: he doesn't have any fixed leaving time in the evening, so what's the problem? But I think that I would still have that first reaction, which is the same for everyone. Say what you like, but when you have been conditioned, your conditioning kicks in before your brain takes over. (Mathias, fortyish, married with children, living in Central Paris, senior executives, arrival around $8: 45$ a.m.)

Generally, however, the employees we spoke to said little about the social control over working hours exercised by management. Of course, they assumed that their arrival and departure times were monitored, but the social control that was mentioned the most and was apparently the most visible came from immediate colleagues:

Although I know that for my actual work, this is a quiet time when there are no deliverables required, I could essentially arrive at 11 o'clock without it disturbing the work in any way at all. I don't do it precisely because I know that people will look at me oddly. (Yves, twentyish, in a relationship, executive, living in the Inner Ring, arrival around 9 a.m.)

\section{Colleagues monitoring equality of working hours: 'Had a nice morning?'}

While the timekeeping norm of the disciplined worker partly has its origins in the hierarchical relations between employee and employer, it only survives because it is supported by the voluntary servitude (de la Boétie, [1576] 2013) of 'courtiers' who collude with the tyrant.

In interpreting our interviews, we should nevertheless qualify De la Boétie's picture. In the field that interests us, the pyramid of social control 
has only two levels. While both tyrannising and tyrannised, our subjects are in fact far from being tyrants. When they monitor timekeeping, they are not usually concerned with dominating other employees 'below them'. They simply want to make sure that everyone is subject to the same dominance as they are. In short, by observing the working hours of others, they act as the guarantors of equality in working hours and their colleagues' work discipline.

Reflecting this principle, some interviewees reported that colleagues had commented on their working hours. These comments always take roughly the same form. Expressed in joking terms, they imply that their colleagues perceive their work schedule as equivalent to taking the morning off:

I've always received comments on my arrival time but never on my departure time from the office! Nobody is there in the evening to check! People who made those remarks had no hierarchical relationships with me. Judgement of colleagues... I think that sometimes colleagues' judgement can have an impact because some of them could complain about my arrival time to the hierarchy. (Aude, fiftyish, divorced with children, executive, living in Central Paris, arrival around 9 a.m.)

We now need to re-situate this norm within the framework of our study and its current context. The main consequence of this disciplinary norm is to bring lost sheep or naughty children back into line, i.e. people who do not seem to be fulfilling their contract by arriving after 9:30 a.m. It has no real effect on the majority of employees who obey the norm, except to reinforce the cohesion of the work collective. However, within our population of mostly management employees, who are relatively autonomous, another peripheral norm seems to be emerging. And as a peripheral norm, this time it has the effect of enhancing the prestige of employees who adopt it.

\section{The norm of the dedicated executive}

In this second subsection, we will look at what the interviewees say about the existence of the norm of the dedicated executive as a norm that prompts executives to arrive at the office before the morning peak. First, we will see that this norm only continues because management interprets early arrivals and long days as an indication of strong commitment. The social benefit gained by employees who acquire visibility by working long hours then encourages competitive relations between the different members of a single work collective. 


\section{Management recognition and assessment of donation}

Historically, French executives have always worked on average longer than other socio-professional categories of employees (Devetter, 2001). In their apparent emotional commitment to their work (Monneuse, 2014), executives literally donate overtime to their employer. However, as with any donation, and regardless of any possible emotional commitment, this rationale is underpinned by the expectation of reciprocity (Mauss, 2002 [1923]). It is with respect to this reciprocity that the executive's line manager plays an extremely important role in perpetuating the timekeeping norm of the dedicated executive.

The timekeeping norm of the dedicated executive is perpetuated because managers continue to value and reward executives who adopt the pattern of long working hours:

If I reformulate what you say, we could say that people who arrive early are hard and committed workers? And conversely, people who arrive late are slackers?

- No, not necessarily, because people who arrive early leave early. Conversely yes, there is still a culture of presenteeism. Yes, I think that French culture is really heavily imbued with this culture of presenteeism. It still shocks me to hear in discussions between managers: ah but he's good, he arrives early and stays late. People who work long hours can do no wrong. (Lætitia, thirtyish, divorced with a child, senior executive, living in the Outer Ring, arrival around 8 a.m.)

The culture of presenteeism that Lætitia talks about is apparently maintained by bosses who primarily value their employees' time 'presence' in the company.

Under the same principle as the timekeeping norm of the disciplined worker, this principle of valuing behaviours is the outcome of cultural learning that is passed on from one generation to the next, from boss to boss. For as this senior executive explains, today's senior executives were yesterday's middle managers and when they need to evaluate their colleagues, they frequently reproduce the same models of hierarchical advancement as yesterday's bosses applied to them:

Yes, I think that this comes more from the executive, because he feels that he had to operate in this way, working long hours, in order to climb the ladder. So unconsciously he believes that it's the right model, and passes it on to his subordinates. He associates long hours with people who are more committed 
and more effective. (Philippe, thirtyish, married with a child, senior executive, living in the Outer Ring, arrival around 9 a.m.)

Here again, we have the phenomenon of hysteresis, where senior executives, rather than responding to new conditions in the exercise and evaluation of performance at work, are often content to reproduce the principles inculcated by their 'professional fathers', but now in a very different context.

As the service sector has grown, the output of an executive's work is increasingly immaterial and multiform. In parallel, the continuing progress in communication and information technologies increasingly separates the value of a finished product from the time taken to produce it (du Tertre, 2005). Yet executives who spend the most time at work continue to be rewarded. There is no sign that the timekeeping norm of the dedicated executive is likely to change any time soon. For that to happen, both senior executives and executives lower down the ladder would have to be able to establish an alternative model of labour value that would not necessarily be based on an assessment of 'working time'.

\section{The executive's subjective commitment to competition between colleagues over working time}

In opposition to the culture of presenteeism, but also to the idea of discipline inherited from the industrial era, we are increasingly seeing the emergence and promotion of concepts like the 'happy manager' or the 'liberated business' (Ughetto, 2018). However, these ideas, often inspired by the models of organisation practised in start-ups, are not necessarily seen in such a positive light by employees.

Would you like to be seen taking a nap at the office? People don't do it, even if they feel sleepy. Would you like to be seen playing table football? Nobody plays. People don't want to be seen playing table football. These are all HR gimmicks. Believe me, happy managers, the liberated business, all those fads, we've seen them all. And in fact, what gets in the way is self-image. People don't want to be remembered as the guy asleep in a hammock. (David, fortyish, married with children, senior executive, living in Outer Paris, arrival around 10:45 a.m.)

If employees were genuinely sure of keeping their jobs or being able to advance despite playing table football or regardless of the time they arrive at work, this alternative compromise could have an effect. In current circumstances, however, this change of 'management model' and this 'liberation of 
businesses' seems rather to be having the opposite effect, with increased competition between employees, primarily over the length of their working day.

Speaking of his recent professional experience, Jean confirms the truth of this paradox. Greater autonomy in working hours and their apparent detachment from regulatory constraints encourage employees to differentiate and choose their working times. But at a time when employees are under pressure from the fear of redundancy, this increased choice becomes just another way to demonstrate one's commitment and keep one's job when downsizing decisions are made.

Before joining (...) I worked in a consulting and audit firm, and yes there was this sort of unhealthy competition: who's already there when the boss arrives? And who stays the longest? Pressure linked with whether or not you are effective, productive, which is directly linked with the number of hours spent at work. So you feel forced to come early and leave late.

- What do you think is the source of this norm?

- For me, it's obvious. In the consulting firm where I worked, staff turnover was $25 \%$ a year and essentially, though it was never said, never stated, it was the spirit of competition. Because every year you were expected either to progress or leave! So of course everyone was keen to be one of the ones who would be kept on or get a raise. (Jean, thirtyish, single, executive, living in the Inner Ring, arrival around 9:30 a.m.)

This result can be better understood by interpreting it in the light of Philippe Zarifian's analysis (Zarifian, 2004). According to this author, the facets of executive working time management reveal an underlying trend in our society: the deconstruction of a 'disciplinary' society and the transition to a society of 'monitoring of subjective commitment'. And it is in this way, according to Roland Gori, that 'the primary imperative of selforganisation, self-constraint in working time is nothing other than a permanent effort to outperform both oneself and others' (2013: 51), particularly in trying to always be the first through the office door.

\section{Social norms on working hours maintained by HR managers}

Having considered the words of employees themselves, and how they successively reveal the channelling effects of two norms of working hours, we will now show that these two timekeeping norms can also be 


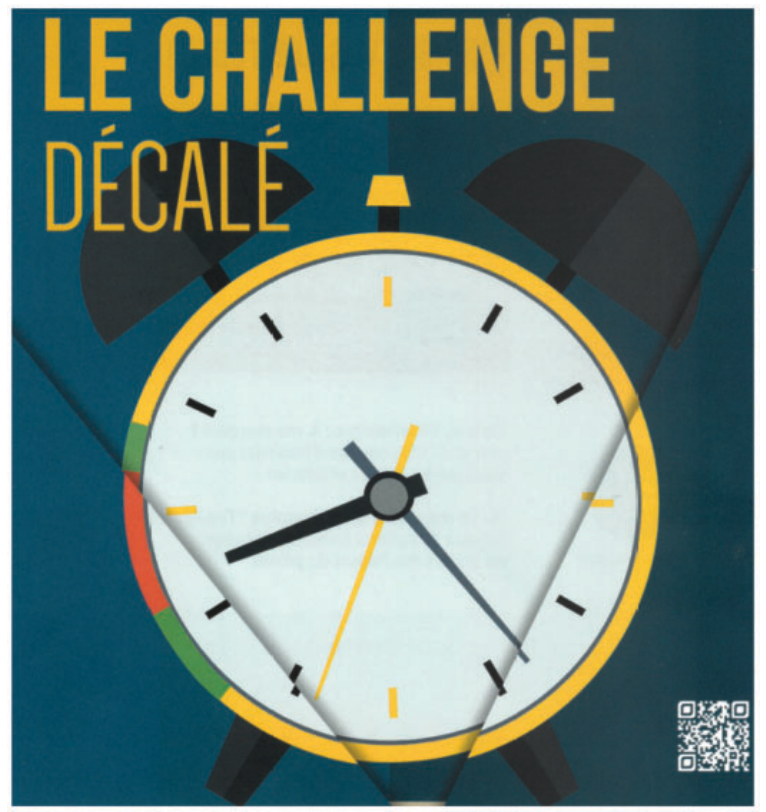

Figure 2. Visual advertising for the Challenge Décalé.

Source: Flyer of the Challenge Décalé distributed in front of the RER stations of the Plaine Saint-Denis.

found among HR managers. For this, we will draw on a concrete example: the development of a competitive game to encourage employees to travel outside peak times, the Challenge Décalé ${ }^{11}$ (Figure 2).

\section{The rules of the Challenge Décalé and the choice of winning timeslots}

The principle of the game was simple: from 16 November to 4 December 2015, employees who arrived at one of the two RER stations in Plaine Saint-Denis before or after the peak period could accumulate points and ultimately win prizes.

The discussions that led the HR managers to decide the 'off-peak' timeslots for which points were awarded were very interesting. The utility of observing these discussions for our purposes was as follows: the way in which HR managers valued and 'rewarded' certain timeslots rather than others provides empirical insight into their representations and the social norms on working hours maintained by employers.

At the first meetings on the Challenge Décalé project, the participants were given foot traffic statistics on the peak period (8:30-9:30 a.m.). Despite 


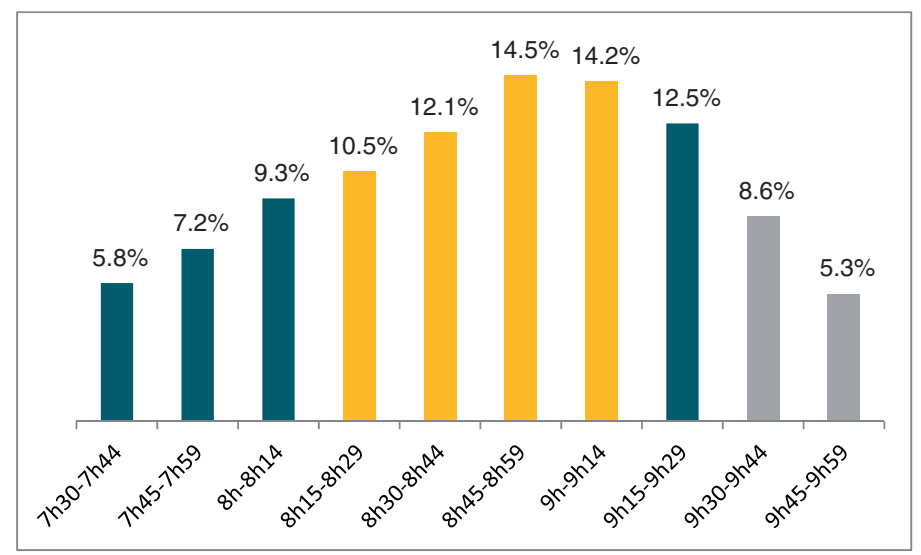

Figure 3. Distribution of exit times at the RER B and D Stations in La Plaine, per 15-minute timeslot, and colouring of the timeslots chosen for the game.

Legend: The height of the bars indicates foot traffic in the station, in 15-minute timeslots. The point-scoring 'pre-peak' (7:30 a.m.-7:44 a.m.) and 'post-peak' (9:15 a.m.-9:30 a.m.) slots are in blue. The non-point-scoring 'peak period' (8:15-9:15 a.m.) is in yellow. The timeslots that are ineligible for the game are in grey. ${ }^{12}$

Source: Station exit data for all working Mondays in 20I5. Pôle TVV-SNCF Transilien.

the data, the HR managers nevertheless chose to bring the peak period for the purposes of the game (the period ineligible for points) forward slightly, to between 8:15 a.m. and 9:15 a.m. As a result, the point-scoring pre-peak period was positioned between 7:30 a.m. and 8:15 a.m., and the post-peak period between 9:15 and 9:30 a.m.

This demarcation of the point-scoring timeslots represents a distortion relative to the actual distribution of traveller flows (Figure 3). In this sense, bringing forward the peak period from 8:30-9:30 a.m. to 8:15-9:15 a.m., and the unequal distortion of the pre-peak and postpeak periods, are a perfect illustration of compliance with the two norms described above.

\section{Preventing late arrivals and encouraging early arrivals}

On the one hand, the timekeeping norm of the disciplined worker must be obeyed and it was inconceivable to encourage workers to arrive after 9:30 a.m. This explains why the peak period was brought forward by some 15 minutes in order to construct a post-peak period between 9:15 and 9:30 a.m. On the other hand, the timekeeping norm of the dedicated executive is well evidenced, since the dissymmetry between the pre-peak and 
post-peak periods encourages early arrivals and greater commitment to work: while the 'slackers' need to aim for a 15-minute slot after the peak, the 'dedicated executives' have three times as many opportunities to arrive before peak time between 7:30 and 8:15 a.m. In fact, one of our interviewees who took part in the Challenge Décalé directly expressed the injustice he felt about this asymmetry in the treatment of early and late arrivals:

The challenge was not very fair, because $80 \%$ of the rewards went to people who arrived before the rush hour.

- That's a real problem. Overall, the companies were reluctant to encourage employees to come to work after peak time.

- I think that there is a huge level of reluctance about this. There is a lack of trust. (Jean, thirtyish, single, executive, living in the Inner Ring, arrival around 9:30 a.m.)

The quest for a consensus around shared values, norms and goals between the different people running the game undoubtedly played a role in the agreement over the point-scoring timeslots. To the point that in the quest for consensus, i.e. the lowest common dominator for acceptable off-peak timeslots, the result came quite close to redefining the peak-hour time thresholds as the two off-peak periods!

I am pernickety - after this I'll leave you in peace - but in fact peak time on the network runs up to 9:30 a.m., so encouraging people to come between 9:15 and 9:30 means encouraging them to be part of the rush hour, not to avoid it.

- Yes, it's more or less the high point of arrival. (Local authority representative)

- I think that what is interesting with this Challenge is not so much the effect on peak time. It's more whether one can have an effect on the habits of employees by communicating and raising awareness about peak-time travel. For me, the impact on the transport systems is not very important. (Telecoms HR manager)

- In addition, you have to realise that there are a good number of employees who don't get to choose their work times. (Public Transport A, B, C HR manager.) 
- Yes, that depends on how the different jobs and companies work. (Telecoms HR manager)

- Yes, for example for people who have duty rosters, they can come early without disrupting work arrangements, but not later. (Public Transport A, B, C HR manager.)

For its part, the role of the legal framework applicable in some companies seems quite clearly questionable: whereas only 'Public Transport C' has a duty roster, 'Public Transport A and B', which belong to the same company, in the end also became subject to the rule of the morning timetable applicable only in 'Public Transport C'. Like the employees at 'Public Transport C', the players at 'Public Transport A and B' could only earn points by arriving at work early. The post-peak arrival timeslot (9:15 a.m. to 9:30 a.m.) was closed to employees in these sections. Yet we know that more than the legal rule, which has ceased to be applicable in this case, it is the custom of morning arrival times that remains very present in all sections of this transport company.

Moreover, while legal rules could be employed to demarcate the start and finish of off-peak times - i.e. what is tolerated or prohibited - they could not be used to differentiate the value of the points awarded on the basis of the time of travel. What is forbidden is forbidden, what is allowed is allowed, but according to the companies' internal rules, there are not supposed to be times that are more strongly allowed - in other words more

Table 2. Points awarded for different station exit times.

\begin{tabular}{lll}
\hline Time (a.m.) & Timeslots & Points awarded \\
\hline 7:30-7:35 & Pre-peak & 150 points \\
$7: 35-7: 40$ & Pre-peak & 140 points \\
7:40-7:45 & Pre-peak & 130 points \\
7:45-7:50 & Pre-peak & 125 points \\
$7: 50-7: 55$ & Pre-peak & 120 points \\
7:55-8 & Pre-peak & 115 points \\
$8-8: 05$ & Pre-peak & 110 points \\
8:05-8:10 & Pre-peak & 105 points \\
8:10-8:15 & Pre-peak & 100 points \\
8:15-9:15 & Peak hour & 0 points \\
$9: 15-9: 20$ & Post-peak & 120 points \\
9:20-9:25 & Post-peak & 125 points \\
$9: 25-9: 30$ & Post-peak & 130 points \\
\hline
\end{tabular}

Source: reproduced with permission from www.lechallengedecale.fr 
recommended - than others. By way of illustration, if we take the example of the company in which the tolerated arrival time range is between 7:30 a.m. and 9:30 a.m., there is in principle nothing in the 'rule' to say that 7:31 a.m. is better than 9:29 a.m.

Yet, as we show in Table 2, the earliest arrivals (7:30 a.m. to 7:40 a.m.) were awarded more points than the latest arrivals (9:25 a.m. to 9:30 a.m.).

This imbalance indicates that the game's designers (the HR managers) assign greater credit to the earliest pre-peak arrivals than the latest postpeak arrivals. And finally, by valuing their employees' very early arrivals more and giving them more points, they once again confirm their adhesion to the values and to the norm of the dedicated executive.

\section{Conclusion}

In a context where more and more employees enjoy relative freedom to choose their time of arrival at work, the objective of this article was to investigate what might explain the persistence of the morning rush-hour phenomenon in Paris region. By contrast with the industrial era, when most working hours were set by employers and the rush-hour phenomenon was attributed to the Fordian organisation of labour and society, here we have proposed explanatory factors that apply at the scale of the 'quasi-microbial operations' (de Certeau, 1984 [1980]) of 'office life'. In the organisation of work, encouragements or explicit orders to arrive at work at a specific time are becoming increasingly rare. That is why we have sought to verify the hypothesis that there exist implicit rules which continue to foster rush-hour travel.

Through a field survey conducted within big service sector firms in the Paris region, we revealed the existence of two social norms on working hours that directly contribute to rush-hour transport congestion: the 'norm of the disciplined worker' and the 'norm of the dedicated executive' (Table 3). Drawing on interviews with executives working flexitime, the results of an experiment with HR managers, as well as foot traffic data from a RER station, these two social norms emerged at three different scales of analysis.

First, these norms have their origin in the evaluative process whereby a worker's integrity is judged by the time at which he or she arrives at work. With regard to representations of the work ethic, an individual who arrives early is perceived by peers and bosses as someone who is dedicated and committed, one who arrives at the same time as everyone else is seen as disciplined and organised, while one who arrives later is viewed as an idler and a shirker.

Second, within the company, these norms can be detected through the way that colleagues and bosses encourage or penalise practices that do or 
Table 3. The two social norms on working hours.

\begin{tabular}{clcl}
\hline & Arrival period & Specific mechanism & Effect on the group \\
\hline $\begin{array}{c}\text { Timekeeping norm } \\
\text { of the disciplined }\end{array}$ & Peak hour & $\begin{array}{c}\text { Penalty for individuals } \\
\text { who arrive after }\end{array}$ & Employee cohesion \\
worker & & $9: 30$ a.m. & \\
$\begin{array}{c}\text { Timekeeping norm } \\
\text { of the dedicated }\end{array}$ & Pre-peak & Advancement for indi- & $\begin{array}{c}\text { Competition } \\
\text { between }\end{array}$ \\
executive & & viduals who arrive & managers \\
\hline
\end{tabular}

Source: reproduced with permission from Munch (2017).

do not fit within the said norms. The social norm of the disciplined worker is mainly detected when colleagues and bosses (through teasing, comments or real professional penalties) punish the 'lost sheep' who come into work too late, i.e. after 9:30 a.m. As for the social norm of the dedicated executive, it takes shape when line managers reward employees (generally middle managers) who distinguish themselves by working longer hours than average and who therefore potentially arrive before the rush hour, in other words before 8:30 a.m.

Third, because the timeframe of the activity situated at the end of a journey directly influences the timeframe of travel, the consequences of these social norms on working hours also affect the structure of peak hours in public transport. Given that the period that precedes the peak (before 9 a.m.) is much busier than the period that follows it (after 9 a.m.), it can fairly be acknowledged that the norm of the disciplined worker and of the dedicated executive are reflected in the asymmetry of the morning travel peaks in Paris region (Munch, 2017).

In consequence, if we want to reduce congestion at the critical time (around 9 a.m.) by 'shifting' commuter flows towards periods when there is spare transport capacity, the main priority is to ensure that some peaktime commuters delay their journeys to arrive at the office after 9:30 a.m. Accomplishing this objective suggests the need to remove the symbolic barrier of social norms on working hours. In order to reduce rush-hour congestion on the Paris transport systems, it is not enough to give employees freedom to choose their own working hours. It is becoming increasingly clear that until we stop rewarding workers who arrive at work early and become more tolerant of some workers within a work collective arriving later than others, rush-hour phenomena will persist.

While our findings could have a practical impact on the everyday lives of many employees, they also have consequences in the theoretical universe of 
the sociology and geography of time. First, working times and hours are still permeated with powerful values, symbols and representations which, although underestimated in work in the geography of time (Schwanen, 2008), unquestionably help to explain why so many employees on flexitime still travel during the rush hour.

Second, in the theoretical universe of the sociology of time, we provide precise empirical data in support of two theses successively advanced by Hartmut Rosa (2013):

- modern subjects are governed, dominated and repressed by a temporal regime that is largely invisible, depoliticised, undiscussed, under-theorised and unarticulated (p. 8);

- temporal norms or 'time regimes' are used to assign recognition and nonrecognition to merit (p. 78).

On the one hand, in the company headquarters surveyed, which stand midway between the Fordian world of wage employment (Bouffartigue, 2012) and the entrepreneurial world of the autonomous executive (Zarifian, 2004), we have shown that our workers are governed by two types of temporal norms that were hitherto largely invisible and undiscussed. By bringing the social norms on working hours into the public arena of debate, we challenge the legitimacy of their persistence and thereby open up political possibilities for their reshaping.

On the other hand, in our case, the norm of the disciplined worker and the norm of the dedicated executive are clearly used as a measure of employees' discipline and dedication to their company. In this way, we propose to consider temporal norms in ethical terms in order more easily to identify the 'temporal symbols' (Elias, 1992 [1984]) that need to be manipulated before we consider our relationship to time within political constructions.

\section{Outlook}

Finally, in order to fully interpret the operational and theoretical conclusions set out above, we propose certain avenues for research that might 'open up' or 'push back' the main limitations inherent in our research approach.

In fact, our investigations focus on the practices of employees belonging to five workplaces. While the characteristics of these workplaces differ in certain respects (employee numbers, business sector, timetable regulation...), they are nevertheless located in the same business hub and offer a fairly uniform picture of the working life of middle executives in 
big national or multinational companies in the Paris region. It is therefore far from necessarily the case that the two social norms identified in our location are duplicated among other kinds of employees with flexible working hours. For example, while it is practically non-existent in our companies, the social norm of the 'laid-back executive' (Thoemmes, 2012) who gets into work relatively late, seems already to be a reality in certain professional and generational contexts.

We therefore need to avoid over-generalising the scope of these social norms, since the ways in which people represent and place value on particular work schedules differ from one culture and region to another. For instance, interviews conducted with individuals who have worked outside France confirmed recent findings published in (Schulz, 2015), which indicate that in Scandinavian countries, long working days are more denigrated and penalised by the work collective. Whereas in France, and particularly in the Paris region, executives who do not watch the clock are valued because they seem committed to their employer, in other countries such practices seem to have markedly less positive connotations (Ruppanner and Huffman, 2014; Poster and Prasad, 2005; Perlow, 2001), since they are likely to be associated with poor organisation or absence of social life. Why such differences? Does the 'mistrust' (Cahuc and Algan, 2007) frequently associated with French cultural traits have an impact on these practices? For French executives, could it be more difficult to genuinely achieve the status of a 'trusted employee' who sets his or her own hours and potentially arrives after the peak hour? And finally, do these sociocultural differences have a visible impact on the commuting times of these executives from different countries as well as on the overall shape of peak travel times?

As well as broadening the socio-professional and sociocultural boundaries of this research, future studies could also explore what would happen in a different sociopolitical universe: a hypothetical future universe in which the attitudes of Western societies to politics would be based on models other than capitalism, models other than those described in particular by Boltanski and Chiapello in The New Spirit of Capitalism (2018 [1999]). Indeed, on the basis of the authors' conclusions in that book, it could also be imagined that if employees with flexible working times mostly begin their day during or before the peak hour, it is not only because of cultural and/or professional characteristics, but also the effect of a certain political and productive order that permeates the cultural and professional spheres. According to The New Spirit of Capitalism, the control exercised within a company today has an increasingly 'self-organized' dimension. In service firms, today's mantra is that the only boss is the customer, which makes every employee an independent contractor directly 
responsible for the proper operation of the organisation. In this way, employees are placed in a position of even greater subordination, no longer towards the employer, but towards consumers or commercial partners who are increasingly demanding and unprepared to accept, for example, the phone not being answered before 9 a.m. or after 7 p.m.

So, we could consider that our workers adhere to social norms on working hours partly because they are afraid of a stigma derived from relations with customers and business partners, and what might be called a synchronised inter-organisational sense of duty. In this case, what would happen when organisations deviate from the norm - and from the organisation imperative of inter-organisational synchronisation - because of some exogenous crisis such as transport disruption or political crisis? When there is a major transport disruption (e.g. caused by snow) and/or a major strike, one would expect that workers would no longer worry about the stigma of arriving after their colleagues. This issue is probably difficult to investigate in a data-driven way because data are lacking on such atypical situations. However, it could provide a very powerful demonstration, from a dynamic perspective, of how social norms on working hours can change as soon as business, transport and political systems are directed to goals other than moving capital and people ever more quickly (Harvey, 1990).

Ultimately, it is clear that these avenues of research would demand exploratory analysis and for the moment remain necessarily incomplete. Nevertheless, I hope that they might be seen as an opportunity to think about how these unspoken injunctions influence the patterns of our daily lives and - why not? - might open up a small channel towards a new sociology of everyday life: a sociology of synchronisations.

\section{Acknowledgements}

I wish to thank Leslie Belton-Chevallier and Gwendal Simon for their invaluable help in proofreading this article.

\section{Declaration of Conflicting Interests}

The author(s) declared no potential conflicts of interest with respect to the research, authorship, and/or publication of this article.

\section{Funding}

The author(s) received a financial support for the research from the Sociéte nationale des chemins de fer français (SNCF) and Agence Nationale Recherche Technologie (ANRT). CIFRE n 2014/0197. 


\section{ORCID iD}

Emmanuel Munch (D) https://orcid.org/0000-0001-9574-5424

\section{Notes}

1. For brevity, we use the term 'HR managers' throughout in reference to human resource managers.

2. By an optimum matching method, the authors define so-called 'standard' days as an average working day of close to eight hours. They begin at 8:20 a.m. and end at 5:30 p.m., in most cases with a midday break lasting an average of 1 hour 20 minutes. Standard days account for one in two days worked (50\%) in France.

3. So-called 'long' days are characterised by an extended average working time of 10 hours 40 minutes. They start earlier (7:35 a.m.) and finish later (7:55 p.m.) than standard working days, and are slightly less likely to include breaks. Long days account for one in five days worked (20\%) in France.

4. Our work draws on findings from doctoral research conducted under a CIFRE (industrial research-based training) agreement with SNCF Transilien, one of the Paris region's two public transport operators. The purpose of this action-research was to work together with a number of companies in Plaine Saint-Denis to find solutions that would encourage their employees to practice staggered start times. It was therefore the partnerships between SNCF Transilien and the five partner companies that gave us an entry into this research into working time practices.

5. Data provided by Plaine Commune's 'Real Estate' department.

6. The Enquête Globale Transport 2010 (EGT 2010 - Global Transport Survey) is a large-scale survey that has been conducted approximately every 10 years since the 1970s with households in the Paris region. It has the advantage of containing both data on the sociodemographic characteristics of individuals in the region and on their day-to-day local travel. Of the 32,241 individuals surveyed in EGT 2010, the survey includes a sample of 15,856 active working people in Paris region.

7. Calculations by the author.

8. The pattern of station exit times is largely the same for the RER B station and the RER D station.

9. Relative to our total study population, our interview sample includes many more women, parents with school-age children, highly educated individuals (Master's level), senior executives, homeworkers, employees with free work schedules and also people with long RER commutes.

10. Hysteresis is a notion borrowed from physics in reference to a phenomenon that tends to persist although its original cause has ceased to exist. By analogy, one could advance the idea that the requirement for simultaneous working hours persists although the scientific organisation of industrial production that explicitly underpinned this requirement no longer exists.

11. The literal translation would be the Staggered Challenge.

12. The pre-7:30 timeslot was also ineligible for the game. 


\section{References}

Ariès P and Duby G (1999) Histoire de la vie privée. Tome 5. IDe la Première Guerre Mondiale à nos jours. Paris, France: Éditions du Seuil.

Ascher F (1998) Du vivre en juste à temps au chrono-urbanisme. Les annales de la recherche urbaine 77: 112-122.

Baudoin S (1975) Les horaires de travail en 1974. Économie et statistique 69: 7-17.

Belton-Chevallier L (2009) Mobilités et lien social: Sphères privées et professionnelle à l'épreuve du quotidien. PhD Thesis, Université Paris-Est, France.

Blumer H (1969) The methodological position of symbolic interactionism. In: Cliffs E (ed) Symbolic Interactionism. Upper Saddle River, NJ: Prentice Hall, pp.1-60.

Boltanski L and Chiapello E (2018 [1999]) The New Spirit of Capitalism. New York, NY: Verso.

Boltanski L and Goldhammer A (1987 [1982]) The Making of A Class: Cadres in French Society. Cambridge, UK: Cambridge University Press.

Bouffartigue P (2012) Temps de travail et temps de vie. Les nouveaux visages de la disponibilité temporelle. With the collaboration of Bouteiller Jacques. Paris, France: PUF.

Boulin J-Y and Lesnard L (2016) Travail dominical, usages du temps et vie sociale et familiale: Une analyse à partir de l'enquête Emploi du Temps. Économie et Statistiques 486-487: 148-182.

Bourdieu P (2002) Le Bal des célibataires. Crise de la société paysanne en Béarn. Paris, France: Ed. du Seuil.

Breedveld K (1998) The double myth of flexibilization: Trends in scattered work hours and differences in time-sovereignty. Time \& Society 7: 129-143.

Bunel M (2004) Modulation/annualisation dans le cadre des 35 heures: Entreprises et salariés sous contrainte. Travail et Emploi 98: 51-65.

Burkinshaw J (2018) The tenuous and complex relationship between flexible working practices and travel demand reduction. In: Hui A, Day R and Walker G (eds) Demanding Energy. Basingstoke, UK: Palgrave Macmillan.

Cahuc P and Algan Y (2007) La société de défiance. Comment le modèle social français s'autodétruit. Paris, France: Presses de l'ENS.

Castells M (1996) The Rise of the Network Society: The Information Age: Economy, Society, and Culture Volume I. Hoboken, NJ: Wiley-Blackwell.

Cousin O (2004) Les Cadres: Grandeur et incertitude. Paris, France: L'Harmattan. de Certeau M (1984 [1980]). The Practice of Everyday Life. Berkeley, CA: University of California Press.

Devetter F-X (2001) L'économie de la disponibilité temporelle au travail: La convention fordiste et ses remises en cause. PhD Thesis, Université de Lille I, France.

Dupré M and Lallement M (2007) Regulation of working time in SMEs of the information and communication technology sector in France. New Technology, Work and Employment 22: 66-82.

Elias N (1992 [1984]). Time: An Essay. Oxford, UK: Blackwell.

Epstein CF (1988). Deceptive Distinctions: Sex, Gender, and the Social Order. New Haven, CT: Yale University Press. 
Estrade A, Méda D and Orain R (2001). Les effets de la réduction du temps de travail sur les modes de vie: Qu'en pensent les salariés un an après? DARES Premières Synthèses 21.1: 1-8.

Foucault M (1975). Discipline and Punish. The Birth of the Prison. New-York, NY: Vintage Books.

Gadéa C (2003) Les cadres en France: Une énigme sociologique. Paris, France: Éditions Belin.

Glorieux I ,Mestdag I and Minnen J (2008) The coming of the 24-hour economy? Changing work schedules in Belgium between 1966 and 1999. Time \& Society 17: 63-83.

Godard F (2007) Vie publique et vie privée: de nouveaux régimes temporels. Réseaux 140: 29-65.

Gori R (2013) La Fabrique des Imposteurs. Arles, France: Actes Sud.

Grossin W (1996) Pour une science des temps - Introduction à l'écologie temporelle. Toulouse, France: Octares.

Harvey D (1990) The Condition of Postmodernity. Hoboken, NJ: Wiley.

Hubert H (1929 [1905]) Étude sommaire de la représentation du temps dans la religion et la magie. In: Hubert $\mathrm{H}$ and Mauss $\mathrm{M}$ (eds) Mélanges d'histoire des religions. Paris, France: Alcan.

Kaufmann J-C (1996) L'entretien compréhensif. Paris, France: Nathan.

de La Boétie E (1947 [1576]) Anti-dictator. New York, NY: Columbia University Press.

Lefebvre H (2002 [1961]) Critique of Everyday Life: Foundations for a Sociology of the Everyday (Vol. 2). New York, NY: Verso Books.

Leroi-Gourhan A (1965) Le geste et la parole: La mémoire et les rythmes (Vol. 2.). Paris, France: Albin Michel.

Lesnard L (2006) Flexibilité des horaires de travail et inégalités sociales, Conditions de travail et relations professionnelles. Données sociales - la société française 4: 371-378.

Mauss M (2002 [1923]) The Gift: The Form and Reason for Exchange in Archaic Societies. London, UK: Routledge

Mead GH (2015 [1934]) Mind, Self and Society. Chicago, IL: University of Chicago Press.

Monneuse D (2014) Le silence des cadres. Paris, France: Vuibert.

Munch E (2019) The irresistible peak-hour: Instrumental and axiological rationales of work hours' synchronisation. Transportation Research Interdisciplinary Perspectives 3: $100063.10 .1016 /$ j.trip.2019.100063.

Munch E (2017) Mais pourquoi arrivent-ils tous à la même heure? Le paradoxe de l'heure de pointe et des horaires de travail flexibles. Enquête sociologique auprès de cadres franciliens. PhD Thesis, Université Paris-Est, France. Available at: https://tel.archives-ouvertes.fr/tel-01699034

Perlow LA (2001) Time to coordinate: Toward an understanding of work-time standards and norms in a multicountry study of software engineers. Work and Occupations 28: 91-111.

Pierce JL and Newstrom JW (1980) Toward a conceptual clarification of employee responses to flexible working hours: A work adjustment approach. Journal of Management 6: 117-134.

Pillon V (2003) Normes et déviances. Paris, France: Bréal. 
Poster WR and Prasad (2005) Work-family relations in transnational perspective: A view from high-tech firms in India and the United States. Social Problems 52: 122-146.

Pritchard E (2011 [1940]) The Nuer: A Description of the Modes of Livelihood and Political Institutions of a Nilotic People. Oxford, UK: Clarendon Press.

Pronovost G (1996). Sociologie du temps. Louvain-la-Neuve, Belgium: De Boeck Université.

Rosa H (2013). Social Acceleration: A New Theory of Modernity. New-York, NY: Columbia University Press.

Ruppanner L and Huffman ML (2014) Blurred boundaries: Gender and workfamily interference in cross-national context. Work and Occupations 41: 210-236.

Sautory O and Zilloniz S (2015) De l'organisation des journées à l'organisation de la semaine: Des rythmes de travail socialement différenciés. Économie et Statistique 478: $155-188$.

Schulz JM (2015) Winding down the workday: Zoning the evening hours in Paris, Oslo, and San Francisco. Qualitative Sociology 38: 235-259.

Schwanen T (2008) Struggling with time: Investigating coupling constraints. Transport Reviews 28(3): 337-356.

Szalaï A (1972) The Use of Time: Daily Activities of Urban and Suburban Population in Twelve Countries. The Hague, the Netherlands: Mouton.

du Tertre C (2005) Services immatériels et relationnels: Intensité du travail et santé. Activités Varia 2: 37-49.

Thoemmes J (2012) La mesure des temps des cadres: Une solution pour sortir des difficultés professionnelles? Temporalités 16.

Thoemmes J (2013) L'histoire oubliée des horaires individualisés: de la désynchronisation choisie à la flexibilité pour l'entreprise. Revue Française de Socio-Économie 11: 35-53.

Thorauge M, Cherchi E and Rich J (2016) How flexible is flexible? Accounting for the effect of rescheduling possibilities in choice of departure time for work trips. Transportation Research Part A 86: 177-193.

Thompson EP (1967) Time, work-discipline and industrial capitalism. Past \& Present 38: 56-97.

Ughetto P (2018) Organiser l'autonomie au travail - Travail collaboratif, entreprise libérée, mode agile ...L'activité à l'ère de l'auto-organisation. Paris, France: FYP éditions.

Vickrey WS (1969) Congestion theory and transport investment. American Economic Review, Papers and Proceedings 59: 251-260.

Weber M (2013 [1904]) The Protestant Ethic and the Spirit of Capitalism. Abingdonon-Thames, UK: Routledge

Zarifian P.(2004) Travail, modulation et puissance d'action. L'Homme et la Société 2: 201-227. 10.3917/lhs.152.0201

Zerubavel E (1981) Hidden Rythms. Berkeley, CA: University of California Press. 